\title{
Thermal requirements, heat use efficiency and plant responses of Indian mustard (Brassica Juncea) for different levels of nitrogen under different environments
}

\author{
P.KEERTHI*, R.K.PANNU, RAJ SINGH and A.K.DHAKA \\ Department of Agronomy, College of Agriculture, CCS Haryana Agricultural University, Hisar-125004 \\ *corresponding author: sharmakittu26@gmail.com
}

\begin{abstract}
Field experiment was conducted during rabi 2013-14 and 2014-15 to study the thermal requirement for Indian mustard at research farm, College of Agriculture, Hisar, Haryana (latitude $29^{\circ} 10^{\prime} \mathrm{N}$ and longitude $75^{\circ} 36^{\prime} \mathrm{E}$ Latitude). The experiment was laid out in split plot design with three replications consisted four dates of sowing (Oct $15^{\text {th }} \& 25^{\text {th }}$ and Nov $\left.5^{\text {th }} \& 15^{\text {th }}\right)$ as main plots and five nitrogen levels ( $($ Control), 40, 60, 80 and $100 \mathrm{~kg} \mathrm{~N} \mathrm{ha}^{-1}$ ) as sub plots treatments. Results revealed that duration of phenological stages and thermal unit during days to $50 \%$ flowering to maturity increased with successive delay in sowing. October 15 sowing crop produced significantly higher total dry matter accumulation, more number of siliquae, higher seed yield, and biological yield as compared to October 25, November 5 and November 15. Among the doses of nitrogen, $100 \mathrm{~kg} \mathrm{Nha}^{-1}$ exhibited significantly higher total dry matter accumulation, heat use efficiency, more number of siliquae plant ${ }^{-1}$, higher 1000 seed weight, seed yield and biological yield followed by $80,60,40$ and $0 \mathrm{~kg} \mathrm{~N}$.
\end{abstract}

Keywords: Indian mustard, sowing dates, nitrogen levels, thermal unit and yield attributes.

Rapeseed-mustard (Brassica spp.) is a major group of oilseed crop of the world being grown in 53 countries across the six continents, with India being the second largest cultivator after China (Hedge, 2005). In India it is cultivated on 6.70 million hectares with production of 7.96 $\mathrm{mt}$ and productivity of $1188 \mathrm{kgha}^{-1}$ in 2013-14. Haryana is one of the major rapeseed and mustard growing state and crop occupied 5.40 lakh ha of area producing 8.8 lakh tonnes giving an average yield of $1639 \mathrm{kgha}^{-1}$ (Anonymous, 2014). Among several factors causing low productivity, lack of suitable time of sowing is a crucial aspect in ultimate success of mustard commercial crop. As sowing time is one of the most important non monetary input affecting crop yield and other agronomic traits among them, optimization of sowing time for mustard is essential. Sowing either too early or too late has been reported unfavorable (Uzan et al., 2009). The optimum time of sowing can provide congenial conditions to have maximum light interception, best utilization of moisture and nutrients from early growth stage to seed filling stage. Sowing time is very important for mustard production (Mondal et al., 1999). Late sown Indian mustard is exposed to high temperature coupled with high evaporative demand of the atmosphere during reproductive phase (ripening and grain filling) which consequently results in forced maturity and low productivity. The time of sowing is the main factor which decides the environmental conditions of a crop is likely to encounter during its growing period, timing and rate of organ appearance. Tripathi et al., (2007) reported that the early onset of flowering in mustard results in early siliquae development and extended reproductive phase and ultimately higher seed yield under Hisar conditions. One month delay in sowing from mid October resulted in loss of $40.6 \%$ in seed yield (Lallu et al., 2010). It suffers from exposure to low temperature during vegetative and early pod filling stage and relatively higher temperature during germination and maturity (Adak and Chakravarthy, 2010). Temperature cannot be manipulated easily under field conditions but seeding time can be so adjusted that the various physiological stages of the crop can coincide with specific (most suitable) temperature during crop growth cycle, which is the most essential non-monetary input for obtaining higher production. Among the agronomic factors, fertilizer stands first and is one of the most productive inputs in agriculture. Plant nutrition is a key input to increase the productivity of mustard crop. Among the major nutrient elements, nitrogen which is insufficient in most of the Indian soils plays an important role in Brassica crops. Nitrogen is considered to be the most important nutrient for the crop to activate the metabolic activity and transformation of energy, chlorophyll and protein synthesis. Singh and Meena (2004) observed that the nitrogen affects uptake of other essential nutrients and it helps in the better partitioning of photosynthates to reproductive parts which increase the seed:stover 
ratio.Keeping all these points in view, the present investigation was under taken for investigating the thermal requirements, Heat Use Efficiency and Plant Responses of Indian Mustard (Brassica Juncea) under different Nitrogen level and different weather conditions for different phenological stages.

\section{MATERIALS AND METHODS}

The experiment was conducted at the Agronomy Research farm of Chaudhary Charan Singh Haryana Agricultural University, Hisar (India). Hisar is located in Indogangetic plains of North-West India at 215.2 meters above mean sea level with a latitude $29^{\circ} 10^{\prime} \mathrm{N}$ and longitude 75 36' E during rabi 2013-14 and 2014-15. Hisar has a semiarid climate with hot and dry desiccating winds accompanied by frequent dust storms of high velocity in summer, severe cold during winter and humid warm during monsoon rainy months. The mean monthly maximum and minimum temperature show a wide range of fluctuation during a year. The maximum temperature sometimes exceeds $45^{\circ} \mathrm{Cduring}$ summer, while temperature below freezing point accompanied by frost in winter is usually experienced in this region. The annual rainfall is about $425 \mathrm{~mm}$ and the total rainfalls as well as its distribution are subjected to great variations. About 80 to 90 percent of total rainfall is received from south-west monsoon during the months of July to September. During December - January or in late spring, a few showers of cyclonic rains are also a common feature in this zone. Mean relative humidity (at 7:00 am) remains nearly constant at about 80 to 90 per cent during July to march and then steadily decreases to 40 to 50 per cent by the end of April and remains so till June. Meteorological data were recorded at the agro-meteorological observatory located near to the Research Farm of Chaudary Charan Singh Haryana Agricultural University, Hisar

The soil of the experimental field was sandy loam, having $0.57 \%$ organic carbon and $\mathrm{pH} 8.73$. It was low in available $\mathrm{N}\left(155 \mathrm{kgha}^{-1}\right)$, medium in available $\mathrm{P}_{2} \mathrm{O}_{5}(23.2 \mathrm{~kg}$ $\left.\mathrm{ha}^{-1}\right)$ and rich in available $\mathrm{K}_{2} \mathrm{O}\left(395.6 \mathrm{kgha}^{-1}\right)$. The experiment consisting of four dates of sowingOct $15^{\text {th }} \& 25^{\text {th }}$ and Nov $5^{\text {th }} \&$ $15^{\text {th }}$ in main plots and five nitrogen levels $\left(0 \mathrm{~kg} \mathrm{Nha}^{-1}\right.$ (Control), $40 \mathrm{~kg} \mathrm{ha}^{-1}, 60 \mathrm{~kg} \mathrm{Nha}^{-1}, 80 \mathrm{~kg} \mathrm{Nha}^{-1}$ and $\left.100 \mathrm{~kg} \mathrm{Nha}^{-1}\right)$ in sub plots was laid out in split plot design with three replications. The doses of nitrogen were applied in the form of urea. Half dose of the recommended nitrogen was applied as basal dose and remaining half dose as top dressing after First irrigation during both the seasons. Indian mustard cv. RH
0749 was sown with the help of seed drill in rows $30 \mathrm{~cm}$ apart at a rate of $5 \mathrm{~kg} \mathrm{ha}^{-1}$. Crop was sown as per treatments. The weeds were removed by long tine hoe at 30 and 60 days after sowing (DAS). Total dry matter accumulation $\left(\mathrm{g} \mathrm{m}^{-2}\right)$ was recorded at 30, 60, 90, 120 and at physiological maturity. Yield attributes were recorded from the five plants sample collected at the time of harvest. The crop harvested from net plot area was converted into seed yield $\left(\mathrm{kgha}^{-1}\right)$ and biological yield $\left(\mathrm{kgha}^{-1}\right)$. The cumulative thermal units $\left({ }^{\circ} \mathrm{C}\right.$ day) at various phonological stages were determined by summing the daily mean temperature above the base temperature $\left(\mathrm{T}_{\mathrm{b}}=5^{\circ} \mathrm{C}\right)$ by using the formula as per Nuttonson (1955).

Heat use efficiency (HUE), which is a measure of amount of dry matter production per unit of thermal unit, was worked as per procedures reported by Sahu et al. (2007).

\section{RESULTS AND DISCUSSION}

\section{Phenophases and thermal units}

Duration and accumulated thermal unit of different phenophases during the entire growth period of Indian mustard decreased with each 10 days successive delay in sowing from October 15 to October 25, November 5 and November 15 (Table 1). The October 15 sown crop took longer duration for maturity (146 days) than the later sown crops due to fulfillment of thermal unit requirements in more days and also due to increased vegetative and reproductive phase duration. The total accumulated thermal unit during the entire growth period of the crop decreased from $2288^{\circ} \mathrm{C}$ day under October 15 sowing to $2262^{\circ} \mathrm{Cday}, 2225^{\circ} \mathrm{C}$ day and $2125^{\circ} \mathrm{C}$ day under late sowings on October 25 , November 5 and November 15, respectively. Ten day successive delay in sowing fromOctober 15 to October 25, November 5 and November 15 reduced the crop duration by1, 4 and 11 days, respectively and accumulated thermal units by 26,65 and $163^{\circ} \mathrm{C}$ days, respectively. These findings are in confirmation with Singh et al., (2014).

Among the doses of nitrogen, highest number of heat units consumed were $2230^{\circ} \mathrm{C}$ day for $100 \mathrm{~kg} \mathrm{~N} \mathrm{ha}^{-1}$, followed by $80 \mathrm{~kg} \mathrm{~N} \mathrm{ha}^{-1}\left(2223^{\circ} \mathrm{C}\right.$ day), followed by $60 \mathrm{~kg} \mathrm{Nha}^{-}$ ${ }^{1}\left(2216^{\circ} \mathrm{C}\right.$ day $)$ and $40 \mathrm{~kg} \mathrm{Nha}^{-1}\left(2200^{\circ} \mathrm{C}\right.$ day $)$. The lowest heat units were consumed by $0 \mathrm{~kg} \mathrm{Nha}^{-1} 2193^{\circ} \mathrm{C}$ day. Among the doses of nitrogen, $100 \mathrm{~kg} \mathrm{Nha}^{-1}$ had higher thermal unit requirement due to comparatively increase in crop duration by two days in well fertilized crop over control. Higher doses of nitrogen enhances the cell division and enlargement, the new tissue developed the younger leaves, which slow 
Table 1: Days taken to attain different growth stages in Indian mustard and accumulated thermal units as affected by various treatments (pooled data over two years 2013-14 and 2014-15)

\begin{tabular}{lllll}
\hline Treatments & $\begin{array}{l}\text { Days to 50\% } \\
\text { flowering }\end{array}$ & $\begin{array}{l}\text { Days to 50\% } \\
\text { pod formation }\end{array}$ & $\begin{array}{l}\text { Days to physiological } \\
\text { maturity }\end{array}$ & $\begin{array}{l}\text { Duration of reproductive } \\
\text { phase }\end{array}$ \\
\hline Sowing dates & & & & \\
Oct. 15 & $55(1113)$ & $90(1481)$ & $146(2288)$ & $91(1174)$ \\
Oct. 25 & $58(1158)$ & $91(1496)$ & $145(2262)$ & $87(1104)$ \\
Nov. 5 & $62(1217)$ & $93(1529)$ & $142(2225)$ & $80(1008)$ \\
Nov. 15 & $65(1258)$ & $94(1541)$ & $135(2125)$ & $71(866)$ \\
CD $(\mathrm{P}=0.05)$ & 1.2 & 0.8 & 0.4 & 1.3 \\
Nitrogen levels (kg N ha-1) & & & \\
0 & $57(1144)$ & $90(1496)$ & $141(2193)$ & $83(1049)$ \\
40 & $58(1150)$ & $91(1508)$ & $141(2200)$ & $83(1049)$ \\
60 & $59(1167)$ & $91(1508)$ & $142(2216)$ & $83(1048)$ \\
80 & $60(1190)$ & $93(1529)$ & $142(2223)$ & $83(1032)$ \\
100 & $65(1258)$ & $96(1542)$ & $142(2230)$ & $79(971)$ \\
$\mathrm{CD}(\mathrm{P}=0.05)$ & 1.0 & 0.5 & 0.4 & 1.0 \\
\hline
\end{tabular}

Figure in parenthesis are accumulated thermal units in ${ }^{\circ} \mathrm{Cdays}$

Table 2: Total dry matter accumulation $\left(\mathrm{g} \mathrm{m}^{-2}\right)$ and heat use efficiency $\left(\mathrm{gm}^{-2^{\circ}} \mathrm{C}\right.$ day $)$ of Indian mustard affected by various treatments (pooled data over two years2013-14 and 2014-15)

\begin{tabular}{llllll}
\hline Treatments & At 30 Days & At 60 Days & At 90 Days & At 120 Days & At maturity \\
\hline Sowing dates & & & & & \\
Oct. 15 & $25.2(0.037)$ & $177(0.150)$ & $1130(0.744)$ & $2923(1.537)$ & $3190(1.294)$ \\
Oct. 25 & $22.0(0.037)$ & $164(0.155)$ & $1000(0.734)$ & $2732(1.452)$ & $2886(1.177)$ \\
Nov. 5 & $19.3(0.035)$ & $160(0.170)$ & $849(0.659)$ & $2558(1.451)$ & $2698(1.108)$ \\
Nov. 15 & $16.1(0.031)$ & $145(0.165)$ & $774(0.621)$ & $2357(1.364)$ & $2456(1.012)$ \\
CD $(\mathrm{P}=0.05)$ & 1.52 & 4.50 & 28.3 & 26.5 & 30.7 \\
Nitrogen levels $(\mathbf{k g ~ N ~ h a - 1 )}$ & & & & \\
0 & $15.8(0.027)$ & $129(0.127)$ & $757(0.559)$ & $2450(1.347)$ & $2521(1.032)$ \\
40 & $19.0(0.032)$ & $157(0.155)$ & $922(0.681)$ & $2587(1.423)$ & $2710(1.109)$ \\
60 & $20.5(0.035)$ & $169(0.166)$ & $964(0.712)$ & $2682(1.475)$ & $2850(1.166)$ \\
80 & $23.0(0.039)$ & $175(0.172)$ & $1018(0.751)$ & $2714(1.492)$ & $2929(1.198)$ \\
100 & $24.8(0.042)$ & $179(0.176)$ & $1030(0.760)$ & $2770(1.523)$ & $3034(1.241)$ \\
$\mathrm{CD}(\mathrm{P}=0.05)$ & 0.60 & 4.51 & 14.9 & 38.3 & 24.3 \\
\hline
\end{tabular}

Figure in parenthesis are heat use efficiency $\left(\mathrm{gm}^{-2^{\circ}} \mathrm{C}\right.$ day $)$

down the development of phenophases and finally slowed down the process of senescence, hence delayed the maturity (Rehman et al., 2010).

\section{Dry matter accumulation and heat use efficiency}

Total dry matter accumulation $\left(\mathrm{gm}^{-2}\right)$ varied significantly due to different growing environmental at all the phenophases (Table 2). Crop sown on $15^{\text {th }}$ October produced significantly higher total dry matter at all the phenophases followed by $25^{\text {th }}$ October, $5^{\text {th }}$ and $15^{\text {th }}$ November sown crop. The total dry matter accumulation at maturity was decreased by $9.52,15.4$ and $23.0 \%$, respectively by successive delaying in sowing by ten days from October 15 
Table 3: Yield attributes and yields of Indian mustard as influenced by various treatments(pooled data over 2 years).

\begin{tabular}{|c|c|c|c|c|c|}
\hline Treatment & Siliquae/plant & Seeds/siliqua & Test weight $(\mathrm{g})$ & Seed yield $\left(\mathrm{kg} \mathrm{ha}^{-1}\right)$ & Biological yield $\left(\mathrm{kg} \mathrm{ha}^{-1}\right)$ \\
\hline \multicolumn{6}{|l|}{ Sowing dates } \\
\hline Oct., 15 & 363.1 & 12.9 & 6.7 & 2635 & 11828 \\
\hline Oct., 25 & 340.5 & 12.5 & 6.3 & 2445 & 11049 \\
\hline Nov., 5 & 323.9 & 12.4 & 6.1 & 1992 & 9311 \\
\hline Nov., 15 & 278.8 & 12.1 & 5.5 & 1599 & 7606 \\
\hline $\mathrm{CD}(\mathrm{P}=0.05)$ & 27.8 & 0.49 & 0.29 & 211 & 640 \\
\hline \multicolumn{6}{|c|}{ Nitrogen levels $\left(\mathrm{kg} \mathrm{N} \mathrm{ha}^{-1}\right)$} \\
\hline 0 & 232.5 & 11.7 & 5.5 & 1229 & 7823 \\
\hline 40 & 327.8 & 12.2 & 5.9 & 2029 & 9182 \\
\hline 60 & 344.6 & 12.5 & 6.2 & 2377 & 10404 \\
\hline 80 & 358.2 & 12.8 & 6.4 & 2560 & 11025 \\
\hline 100 & 369.8 & 13.1 & 6.7 & 2645 & 11308 \\
\hline $\mathrm{CD}(\mathrm{P}=0.05)$ & 18.7 & 0.37 & 0.51 & 67.0 & 446 \\
\hline
\end{tabular}

Table 4: Correlation coefficient ( $\mathrm{r}$ ) between seed yield and agro meteorological indices

\begin{tabular}{ll}
\hline & Seed yield \\
\hline Heat units & 0.004 \\
HUE & 0.95 \\
Dry matter & 0.92 \\
Biological yield & 0.96 \\
\hline
\end{tabular}

to October 25, November 5 and November 15. Total dry matter accumulation was also differed significantly among the doses of nitrogen and $100 \mathrm{~kg} \mathrm{Nha}^{-1}$ produced significantly higher total dry matter accumulation at all the phenophases followed by $80,60,40 \mathrm{~kg} \mathrm{Nha}^{-1}$. The minimum total dry matter accumulation was produced in control $(0 \mathrm{~kg}$ $\mathrm{Nha}^{-1}$ ).

Results showed that the HUE is increased up to 120 DAS and thereafter declines slightly at maturity. At 60 DAS the heat use efficiency (HUE) was recorded higher for November 5 sown crop $\left(0.170 \mathrm{~g} \mathrm{~m}^{-2 \circ} \mathrm{C}\right.$ days $)$ and the lowest for October 15 sown crop $\left(0.150 \mathrm{~g} \mathrm{~m}^{-2 \circ} \mathrm{C}\right.$ days $)$. However, at 30, 90, 120 DAS October 15 sown crop exhibited higher values of HUE followed by October 25, November 5 and November 15. At maturity, HUE was recorded the maximum for October 15 sown crop $\left(1.294 \mathrm{~g} \mathrm{~m}^{-2 \circ} \mathrm{Cday}\right)$ followed by October $25\left(1.177 \mathrm{~g} \mathrm{~m}^{-2 \circ} \mathrm{C}\right.$ day $)$, November $5\left(1.108 \mathrm{gm}^{-2 \circ} \mathrm{C}\right.$ day). The minimum value for HUE was found to be for November 15 (1.012 $\mathrm{g} \mathrm{m}^{-20} \mathrm{C}$ days) sown crop.Similar findings were recorded by Kumar et al., (2013). Among the doses of nitrogen, the thermal use efficiency increases with an increase in the dose of nitrogen at various growth stages. Maximum thermal use efficiency was recorded in $100 \mathrm{~kg}$ $\mathrm{Nha}^{-1}\left(1.241 \mathrm{~g} \mathrm{~m}^{-2 \circ} \mathrm{C}\right.$ days) at various growth stages and minimum with control i.e $0 \mathrm{~kg} \mathrm{Nha}^{-1}$. Higher heat use efficiency (HUE) was recorded in the early sown crop as compared to late sown crop due to less biomass production and less number of heat units accumulation in delayed sown crop (Table 2). This can be clearly explained by significant relationship between biomass and HUE , $\mathrm{r}=0.94$ (Table 4).

\section{Yield attributes and yield}

Yield attributes and yield were significantly influenced due to different crop growing environments (Table 3). The crop sown on October 15 produced significantly more number of siliquaeplant ${ }^{-1}$, seeds siliqua ${ }^{-1}$, test weight $(\mathrm{g})$, higher seed yield $\left(\mathrm{kg} \mathrm{ha}^{-1}\right)$ and biological yield $\left(\mathrm{kg} \mathrm{ha}^{-1}\right)$ as compared to October 25, November 5 and November 15 sown crops. There was a significant decrease in seed and biological yield with delay in sowing. Early (October 15) sown crop received the optimum environment conditions required for better crop growth in terms of dry matter accumulation and there was a significant positive association between biological yield and dry weight $(\mathrm{r}=0.96)$. The delay in sowing from October 15 to October 25, November 5 and November 15 decreased the seed yield of mustard by about 7.2, 24.4 and $39.3 \%$ respectively. This decrease was because of decreased number of siliqua plant ${ }^{-1}$ by $5.8,10.2$, and $32.6 \%$, respectively. The early sown crops (October 15) maintained better agro meteorological indices in terms of thermal units, heat use 
efficiency(HUE) which helped in maintaining optimal thermal requirements for various plant process hence increased the biological and seed yield. This fact can be supported by significant association between seed yield and thermal units $(\mathrm{r}=0.004)$, seed yield and HUE $(\mathrm{r}=0.95)($ Table 4$)$. These results corroborate the findings of Singh et al. (2014) in mustard.

Among thedoses of nitrogen, $100 \mathrm{~kg} \mathrm{Nha}^{1}$ exhibited significantly more number of siliquae $\left(\right.$ plant $\left.^{-1}\right)$, seeds siliqua${ }^{1}$, test weight $(\mathrm{g})$, higher seed yield $\left(\mathrm{kg} \mathrm{ha}^{-1}\right)$ and biological yield $\left(\mathrm{kg} \mathrm{ha}^{-1}\right)$ followed by $80,60,40$ and $0 \mathrm{~kg} \mathrm{Nha}^{-1}$. Seed yield increased significantly with increase in nitrogen doses up to to $100 \mathrm{~kg} \mathrm{Nha}^{-1}$ (Table3). The significantly higher seed yield (114\%) and biological yield (44.5\%) in $100 \mathrm{~kg} \mathrm{Nha}^{-1}$ over control were because of more availability of nutrients for their growth and development of better yield attributes and yield. The poor nutrition in control affected the seed yield more than biological yield which ultimately resulted in significant reduction in harvest index. Similar trend have been reported by Keivendra et al. (2012).

\section{CONCLUSION}

The present study concluded that sowing of Indian mustard on October 15 exhibited significantly higher growth and yield due to optimal thermal requirements for various plant processes. The thermal unit requirement of mustard decreased with delay in sowing beyond October 15. Among the doses of nitrogen, $100 \mathrm{~kg} \mathrm{Nha}^{-1}$ had higher growth and yield because of higher thermal unit requirement due to comparatively increase in crop duration by two days in well fertilized crop over control.

\section{REFERENCES}

Adak, T. and Chakravarthy, N.V.K. (2010). Quantifying the thermal heat requirement of Brassica in assessing biophysical parameters under semiarid microenvironment. Intern. J. Bimeteorol., 54(4): 365377. Anonmyous (2014).www.Indiastat.com.

Hedge, D.M. (2005). Oilseed scenario in India - past, present and future with special reference to rapeseed-mustard. In: Winter School on Advances in Rapeseed-Mustard Research Technology for Sustainable Production of Oilseeds, National Centre on Rapeseed-Mustard,Sewar, Bharatpur, December 15 to January 04, 2005, pp. 1-15
Keivanrad, S., Delkosh, B., Hossein, A., Shirani, R. and Zandi, P. (2012). The Effect of different rates of nitrogen and plant density on qualitative and quantitative traits of Indian mustard. Advances Environ. Biol. 6(1): 145-152.

Kumar, S., Sairam, R. K. and Prabhu, K.V.(2013). Physiological traits for high temperature stress tolerance in Brassica Juncea. Indian J. Plant Physiol., 18 (1): 89-93.

Lallu, R.S., Baghel, V.S. and Srivastava, S.B.L.(2010). Assessment of mustard genotypes for thermo tolerance at seed development stage. Ind. J. Plant Physiol., 15(1): 36-43.

Mondal, R.I, Biswas, M. Hyder, A.M.Kand Akbar, M.A. (1999). Response of rapeseed genotypes to seed rate and seeding date. Bangladesh J. Agril. Res.,24(1): 83-90.

Nuttonson, M.Y.(1955). "Wheat climate relationships and the use of phenology in ascertaining the thermal and photothermal requirement of wheat." American institute of crop ecology, Washington DC, USA, $388 \mathrm{P}$.

Rehman, S., Khalil, S., Muhammad, F., Rehman, A., Khan, A., Zubair, M. and khalil, I. (2010). Phenology, leafarea index and grain yield of rainfed wheat influenced by organic and inorganic fertilizers. Pak. J. Bot., 42 (5):3671-3685.

Sahu, D.D., Chopada, M.C. and Patoliya, B.M. (2007). Determination of sowing time for chichpea varieties in south Saurashtra, India. J.Agrometeorol., 9:68-73.

Singh, Aand Meena, N.L. (2004). Effect of nitrogen and sulphur on growth, yield attributes and seed yield of mustard (Brassicajuncea) in eastern plains of Rajasthan. Indian J. Agron., 49(3): 186-188.

Singh, M.P. Lallu, Nand Singh, N.B. (2014). Thermal requirement of Indian mustard (Brassica Juncea) at different phenological stages under late sown condition. Indian J. Plant Physiol., 19 (3): 238-243.

Tripathi, M.K. Rao, V.U.M and Singh, D. (2007). Effect of sowing time and in-season growth manipulations on phenology of Indian mustard (Brassica juncea). Ind.J. Agric. Sci., 77(4): 253-257.

Uzun,B., Zengin, U., Furat, S. and Akdesir, O. (2009). Sowing date effects on growth, flowering, seed yield and oil content of canola cultivars. Asian J. Chem. 21: 19571965 